\title{
Enhancing the internal plant colonization rate with endophytic nitrogen-fixing bacteria
}

\author{
G. Kovtunovych, O. Lar, V. Kordyum, D. Kleiner ${ }^{1}$, N. Kozyrovska \\ Institute of Molecular Biology and Genetics of the National Academy of Sciences \\ Vul. Acad. Zabolotnoho, 150, Kyiv, 03143, Ukraine \\ 1 Lehrstuhl fur Mikrobiologie Universitat Bayreuth \\ D-95440 Bayreuth, Germany
}

\begin{abstract}
Several diazotrophic strains of Klebsiella oxytoca and $\mathcal{K}$ terrigena that colonize the plant-host interior were able to produce the plant cell wall depolymerising enzyme pectate lyase (Pel). The activity of the $K$. oxytoca enzyme was weaker than that of phytopathogenic bacteria, and it was located mainly inside the cells. A small fraction of the cells $\left(10^{-6}\right.$ to $\left.10^{-5}\right)$ in populations grown in nonselective media was able to grow in a selective medium with polygalactorunate $(P G)$ as sole carbon source. After passage through selective medium cells were converted to the Pel'-phenotype, and total Pel-activity in population of $K$. oxytoca increased. The increased level of Pel-activity of $K$. oxytoca and $K$. terrigena correlated with a 10-fold higher rate of internal colonization of wheat roots. Cultures of $K$. oxytoca VNI3 grown in selective medium with $P G$ also showed increased stimulation of wheat growth. Seedlings inoculated with such cultures exhibited better development resulting in higher biomass.
\end{abstract}

Introduction. The endophytic bacteria are now considered as a valuable means to reduce the input of chemicals [1]. They may derive significant competitive advantage over soil-born bacteria from their close contact with plants. Living within the plant tissuc, they may protect the plant from superinfection by soil bacteria and recolonize the plant surface after some stress situations in the soil.

Nitrogen-fixing Klebsiella oxytoca VN13 was isolated from the rice root interior in Viet Nam. The bacteria were proven to penetrate into the plant tissue [2]. Bacteria were localized within cells of the peripheral layer of the root tissue, in intercellular space and xylem [3]. Studies on physiological properties of this bacterium have shown that $K$. oxytoca VN13 was capable to excrete auxins and antimicrobial substances [4]. Monitoring the survival of bacteria in the plant rhizosphere by using bioluminescence-based technique revealed their presence on the roots during the plant vegetative period [5].

The mechanism of penetration is yet unknown.

(C)

(i. KOVTUNOVYCH, O. LAR, V. KORDYUM, D. KLEINER,

N. KOZYROVSKA,
The plant-associated bacteria do not possess penetration structures, such as penetration pegs commonly found in fungi. Consequently, all plant-associated bacteria are unable to exert mechanical or physical forces to penetrate intact epidermal cells. The first predicted route for entrance of the endophytic bacteria into the plant tissue is via lateral roots [6]. Once the lateral root threads through the outer epidermal layer to the inside, bacteria may gain entrance through the resulting crevice. Bacteria, invading unwounded roots, can be present in the gaps made by the pushing the newly formed lateral roots through the cortex. Another possibility for bacteria to penetrate into the plant tissue is secretion of enzymes for plant cell wall degradation, such as pectinases, cellulases, and proteases [7]. The pectolytic activity of $K$. oxytoca was documented by von Reisen [8, 9$\}$.

The objectives of this study were to determine how penetration of diazotrophic klebsiellac into the plant interior is related to the production of pectate lyase activity.

Materials and Methods. Bacterial strains used in this study are listed in Table 1. Media for bacterial growth: aminopeptide (AMP) (S. Petersburg, Russia), a minimal medium $M 9$ [11], a nitrogen-free medium 
(NFDM) [1], a medium for seeds germination [12]. Antibiotics were added when appropriate, kanamycin $(\mathrm{Km}), 100 \mu \mathrm{g} / \mathrm{ml}$, and rifampicin (Rf), $100 \mu \mathrm{g} / \mathrm{ml}$. Carboxymethylcellulose (CMC) and sodium polygalacturonate were used at concentration $0.2 \%$. Glycerol $(0.1 \%)$, yeast extract $(0.1 \%)$, and thiamin (20 mg/1) were added to M9 when appropriate.

The saturated solution of copper acetate was used for the pectate lyase activity determination. $0.1 \%$ solutions of Congo red, crystal violet, were used for enzyme activity tests.

Detection of the acetylene reductase (nitrogenase) activity (ARA) was performed as described by Kordyum et al. [1] in nitrogen fixation deficient medium containing different carbon sources.

Seeds of wheat (Triticum durum), variety «Katyusha», were used in laboratory experiments.

Table 1

Bacterial strains

\begin{tabular}{|c|c|c|}
\hline Racterial strains & $\begin{array}{l}\text { Phenotype or } \\
\text { genolype }\end{array}$ & Source or reference \\
\hline $\begin{array}{l}\text { K. oxytoca } \\
\text { ATCC } 13183\end{array}$ & wt & ATCC \\
\hline K. oxytoca M5a 1 & $w t$ & $\begin{array}{l}\text { University of Bayreuth } \\
\text { (FRG) }\end{array}$ \\
\hline K. oxytoca UBM 239 & $\mathrm{Amx}^{+}$ & {$[10]$} \\
\hline K. oxytoca VN13 & $\mathbf{R f}$ & Laboratory collection \\
\hline $\begin{array}{l}\text { K. planticola } \\
\text { ATCC33531 }\end{array}$ & wt & ATCC \\
\hline K. planticola 9 & wt & $\begin{array}{l}\text { All-Russian Inst. for } \\
\text { Agricultural Microbiology }\end{array}$ \\
\hline$K$. terrigena $80-07$ & wt & Uzhgorod University \\
\hline K. sp. UK-7 & wt & Laboratory collection \\
\hline K. sp. UK-48 & wt & Laboratory collection \\
\hline K. sp. UK-19 & wt & Laboratory collection \\
\hline K.sp. VN131 & $w t$ & Laboratory collection \\
\hline K. sp. VN134 & wt & Laboratory collection \\
\hline $\begin{array}{l}\text { K. pneumoniae } \\
\text { JAM } \ 235 !\end{array}$ & - & $\begin{array}{l}\text { Inst. for Applied } \\
\text { Microbiology (Japan) }\end{array}$ \\
\hline $\begin{array}{l}\text { K. pneumoniae } \\
\text { ATCC } 13883\end{array}$ & wt & ATCC \\
\hline E. carotovora 8659 & wt & $\begin{array}{l}\text { Inst. Microbiology and } \\
\text { Virology NASU (Kyiv) }\end{array}$ \\
\hline $\begin{array}{l}\text { Escherichia coli } \\
\text { JM109 }\end{array}$ & $\begin{array}{l}\text { rec Al, thi-, } \\
\text { Rf }\end{array}$ & Laboratory collection \\
\hline
\end{tabular}

Footnote: wt - wild type; $\mathrm{Amx}^{+}-$ammonium excretion positive; thi ${ }^{-}$- thiamin-deficiency; Rf - rifampicin resistance.
Seeds sterilization was carried out with the $« \mathrm{Be}-$ lizna» reagent (Kyiv) $10 \mathrm{~min}$ and washed off 10 times with a sterile water.

Inoculations of seeds with a washed bacterial suspension $\left(10^{8} \mathrm{cfu} / \mathrm{ml}\right)$ were performed, using the surface sterilized seeds. The inoculated seeds were put on a wet sterile paper in Petri dishes. Control seeds were wet with sterile water. Paper filters maintained moist with $\mathrm{N}, \mathrm{C}$-free medium for seeds germination [12]. Inoculated seedlings were grown at room temperature and under natural light.

Reisolation of bacteria from the root interior of 2 -week old seedlings was performed after 2 min sterilization of $50 \mathrm{mg}$ root samples with the reagent «Belizna» (Kyiv), repeated washing with steril water, and mincing them in sterile pots. The minced plant tissue was spread on selective agar with appropriate dilutions.

Detection of CM-cellulase (endoglucanase) activity on agar plates was performed using the Congo red technique: the dye forms a deep pink complex with the $\beta$-glucan substrate (CMC) leaving clear halos around active colonies [13]. CM-cellulase activity was measured in uncentrifuged cultured samples by determining the amount of reducing sugars, released from $\mathrm{CMC}$, by the o-toluidine procedure [14]. $0.5 \mathrm{ml}$ of appropriate sample was added to $2.5 \mathrm{ml}$ of the o-toluidine reagent and incubated at $37{ }^{\circ} \mathrm{C}$ for 15 min, then samples were chilled to stop the reaction and to measure optical density at $\lambda=640 \mathrm{~nm}$. One unit of activity is defined as the amount of enzyme catalyzing the release of $1 \mathrm{mM}$ glucose per min.

Pectolytic activity was evaluated with plating technique described by Cuppels and Kelman [15]. Crystal violet $P G$ containing medium was used to test bacteria for excretion of pectate degrading enzymes and thus formation of blue-green halos aroun colonies and indentation of the medium.

Detection of pectate lyase activity was performed on M9 agar plates supplemented with PG alone or $P G$, yeast extract and glycerol. Clones of bacteria were replicated on the same medium, and after $16 \mathrm{~h}$ of incubation at $30{ }^{\circ} \mathrm{C}$, one set of the plates was flooded with a saturated solution of copper acetate. Patches of bacteria, secreting PL into the medium, were surrounded by halos [15].

Detection of Pel -phenotype in a M-concentration state was performed using washed cultures which were grown overnight in selective $\mathrm{M} 9+\mathrm{PG}$ medium, concentrated to $6.0 \cdot 10^{9} \mathrm{cfu} / \mathrm{ml}(\lambda=600 \mathrm{~nm})$, and inoculated in non-selective medium $\mathrm{M9}+$ glucose. During an $8 \mathrm{~h}$ period the optical density was checked and aliquots were spread on selective and non-selective plates. 
Pectate lyase activity assay was carried out as described by Starr et al. [16] with modifications. Pel activity was tested in cell-free extract of overnight culture, and total activity was estimated in the cell lysate. For assay of $\mathrm{Pel}$ activity the reaction mixture (3 ml) contained: $0.2 \% \mathrm{PG}, 0.3 \mathrm{mM} \mathrm{CaCl}, 0.1 \mathrm{M}$ tris- $\mathrm{HCl}$ buffer $(\mathrm{pH} 8.5), 300 \mu \mathrm{l}$ of the culture sample. The rate of reaction was measured at $37^{\circ} \mathrm{C}$ at $230 \mathrm{~nm}$, using Specord (Germany). One unit of Pel activity is defined as the amount of $P e l$ that produces a change in absorbancy at $37{ }^{\circ} \mathrm{C}$ of 1.0 at $235 \mathrm{~nm}$. The specific $\mathrm{Pel}$ activity was expressed in terms of enzyme units per absorbancy of culture at $600 \mathrm{~nm}$.

Selection of $\mathrm{Pel}^{+}$(pectate lyase-excreting) clones was carried out on M9 agar medium where $0.2 \% \mathrm{PG}$ used as the only carbon source. Bacteria were incubated on that medium during $3-4$ days at $37^{\circ} \mathrm{C}$.

Detection of the ability to macerate the potato discs tissue was performed with $K$. oxytoca VN13 $P e l^{t}$-clones and the parental strain. Potato disks were surface sterilized as desribed above. The bacterial suspension $\left(10^{8} \mathrm{cfu} / \mathrm{ml}\right)$ was dropped on disks and incubated at $37^{\circ} \mathrm{C} 3$ days.

Statistical analysis was performed using the Sigma Plot software. Standard deviations were calculated for each data point.

Results. Detection of CM-cellulase (endoglucanase) and pectinase (pectate lyase) activity of the selected Klebsiella strains. The bacteria listed above were checked for the presence of CM-cellulase and pectinase activity. $K$. oxytoca, $K$. terrigen $a$, and $K$. pneumoniae and new diazotrophic isolates from maize, identified as Klebsiella sp., formed $2-10 \mathrm{~mm}$ halos around colonies when grew on CMC-agar. However, endoglucanase activity estimated on reduced aldehyde groups could not be detected. Strains of $K$. planticola did not grow on CMC-medium.

Only representatives of $K$. pneumoniae grew well in the M9 minimal agar medium supplemented with $0.2 \%$ PG as the only carbon source and formed halos around colonies after flooding respective agar plates with copper acetate solution, indicating lyase activity. Other species of bacteria grew very slowly in PGcontaining medium, however, $K$. oxytoca and $K$. terrigena displayed halos in contrast to $K$. planticola.

When yeast extract $(0.5 \%)$ had been added to the medium containing $P G$, diazotrophic bacteria started to grow, but they did not develop halos after exposure to the copper acetate reagent, demonstrating no or poor Pel-activity outside cells.

Selection and characterization of $\mathrm{Pel}^{+}$(pectate lyase-excreting) clones. Incubating $K$. oxytoca and $K$. terrigena bacteria in $\mathrm{M} 9+\mathrm{PG}$ without agar resulted in a slow growth rate, and after $3-4$ days $10^{3}$ to $10^{4}$ $\mathrm{cfu} / \mathrm{ml}$ were isolated on $\mathrm{M9}+\mathrm{PG}$ plates. These clones left halos around colonies, thus exhibiting $P e l$ activity. Selected clones $\left(\mathrm{Pel}^{+}\right)$grew well $\left(10^{9} \mathrm{cfu} / \mathrm{ml}\right)$ in $\mathrm{M} 9+$ $+\mathrm{PG}$, and all cells possessed the $P e I^{+}$-phenotype, as revealed by the calculation of cells in parallel on selective and non-selective plates. However, after a passage in a medium containing another carbon source (glucose, sucrose, glycerol, yeast extract) than $P G$, the Pel activity returned to the level of a wild type. Some fraction of the cells $\left(10^{-6}\right.$ to $\left.10^{-5}\right)$ retained the $P e I^{t}$-phenotype, but the rest switched off $P G$ utilization.

In the state of $\mathrm{M}$-concentration when bacteria do not multiply and concentation of cells in population is stable $\left(6 \cdot 10^{9} \mathrm{cfu} / \mathrm{ml}\right)$, the numbers of the $\mathrm{Pel}$-cells grown under both selective and non-selective conditions were the same. So in non-selective conditions not all cells of the population changed their status, and the $P e I^{+}$-phenotype has been maintained while cells did not divide.

$\mathrm{T} \mathrm{h}$ e in vitro $\mathrm{pectate} 1$ y a $\mathrm{se}$ a $\mathrm{ct} \mathrm{i} \mathrm{vi}$ $t$ y o f $K$. oxytoca VN13 Pel. Derepression and repression of Pel activities of $K$. oxytoca VN13, the parental type, along with a $K$. oxytoca VN13 Pe $l^{+}$ clone were investigated after growth in M9 supplemented with different carbon sources. The activity was measured both in the cellular supernatant and in the cell lysate. As seen in Table 2, total activity (extra- and intracellular fraction) of $K$. oxytoca VN13 wild type was small, as expected. The Pelt-clone demonstrated a 3 -fold higher $P$ el activity rate in state of derepression, and showed repression of the activity by glycerol and glucose. Interestingly, more Pel activity is located inside cells of $K$. oxytoca VN13 Pel than outside. E. carotovora 8655 served as positive control.

The acetylene reductase acti$v$ i $t$ y of $K$. oxytoca VN13 Pel. The ARA of Pelclones has been measured when bacteria were incubated in different conditions: in NFDM-nitrogen deficient medium, containing $1.5 \%$ sucrose; NFDM1 where sucrose was substituted with $0.2 \% \mathrm{PG}$, in NFDM2, containing $1.5 \%$ PG. Pel-clones reduced acetylene in all media, but the parental type did not develop ARA in NFDM1 and NFDM2 where sucrose was substituted with $P G$. The rate of ARA of Pelclones was higher in NDFM with $P G$ as a carbon source. The rate of ARA of $\mathrm{Pel}$-clones was 3-fold higher than that of the wild type when bacteria grew in NFDM (data not shown).

E f f e c $t \mathrm{Pel}^{+} K$. oxytoca VN13 o n $\mathrm{g} \mathrm{r}$ ow $t h$ of $w$ h e a $t$ s e e d li n g s. $K$. oxytoca VN13 $\mathrm{Pel}^{+}$was used in wheat inoculating experiments in parallel with the wild type. Inoculated seeds (and 
Table 2

Pectate lyase activity of Klebsiella oxytoca VNI3

\begin{tabular}{|c|c|c|c|}
\hline Sirain & Medium & Total PL activity & $\begin{array}{c}\text { PL activity in } \\
\text { medium }\end{array}$ \\
\hline \multirow{4}{*}{$\begin{array}{l}\text { K. oxytoca } \\
\text { VN13 Pet }\end{array}$} & $P G$ & 0.328 & 0.011 \\
\hline & PG + glycerol & 0.075 & 0.016 \\
\hline & Glycerol & 0.010 & 0.000 \\
\hline & Glucose & 0.002 & 0.000 \\
\hline \multirow{4}{*}{$\begin{array}{c}\text { K. oxytoca } \\
\text { VN13, wt }\end{array}$} & PG & 0.113 & 0.003 \\
\hline & PG + glycerol & 0.253 & 0.002 \\
\hline & Glycerol & 0.003 & 0.000 \\
\hline & Glucose & 0.000 & 0.000 \\
\hline \multirow{4}{*}{$\begin{array}{c}\text { E. carotovora } \\
8659\end{array}$} & $P G$ & 1.030 & 0.320 \\
\hline & PG + glycerol & 0.400 & 0.100 \\
\hline & Glycerol & 0.043 & 0.009 \\
\hline & Glucose & 0.046 & 0.005 \\
\hline
\end{tabular}

Table 3

Number of bacteria isolated from the surface sterilized wheat seedling roots, $\mathrm{cfu} / \mathrm{g}$

\begin{tabular}{c|c|c|c|c}
\hline Sample & AMP & M9+PG & LA & M9+PG \\
\hline & & & & \\
Pel & $2.9 \mathrm{E}+4$ & $3.1 \mathrm{E}+4$ & $8.7 \mathrm{E}+4$ & $1.4 \mathrm{E}+6$ \\
wt & $2.9 \mathrm{E}+3$ & $2.8 \mathrm{E}+3$ & $3.1 \mathrm{E}+7$ & $1.0 \mathrm{E}+7$ \\
\hline
\end{tabular}

control seeds rinsed with sterile water) were germinated in dishes on moist paper filters. Two and three week-old seedlings bacterial sirains displayed a positive effect on the plant growth. Height of shoots and length of roots of wheat seedlings treated with $P e t^{+}$-cells, however, were more pronounced and correlated with the inceased biomass of seedlings (Figure).

Reisolation of $K$. oxytoca $V N 13$ Pel f rom the whe at root interior. Reisolation of $P e t^{t}$-clones and wild type of $K$. oxytoca VN13 from wheat seedlings grown in $\mathrm{N}, \mathrm{C}$-free medium on paper filters revealed that $\mathrm{Pe} l^{+}$-clones penetrated into the root interior 10 -fold more efficiently than wild type (Table 3 ).

Number of bacteria of both variants ( $\mathrm{Pel}^{+}$or wt) isolated from the surface sterilized wheat root interior was the same on selective (PG) or nonselective agar.

T e s t i n $\mathrm{g} K$. oxytoca VN13 Pel p o t a $t$ o $t$ i s s u e $m$ a $c$ e $r$ a $t$ i o $n$. Taking into account the difference in excreting PL between Pel and wild type $K$. oxytoca VN13 it was expected that the potato tissue maceration proceeded differently. However, we did not observe any changes on the surface of the potato disks in oculating the latter with suspension of $\mathrm{Pet}^{+}$-clones or wild type and incubating it during a 3-day period.

Discussion. Our previous findings revealed that $K$. oxytoca VN13 survived well during the vegetative period of the plant-host due to it's ecological niche in the plant tissue. The rate of Klebsiella internal colonization was not high $(1.0 \mathrm{E}+3 \mathrm{cfu} / \mathrm{fw} \mathrm{g})$, nothing was known about both role of bacteria located inside tissue and average bacterial cell densities in the plant interior. Endophytic populations of bacteria, colonizing the plant, could play a crucial role in plant growth and development. Endophytes may protect the

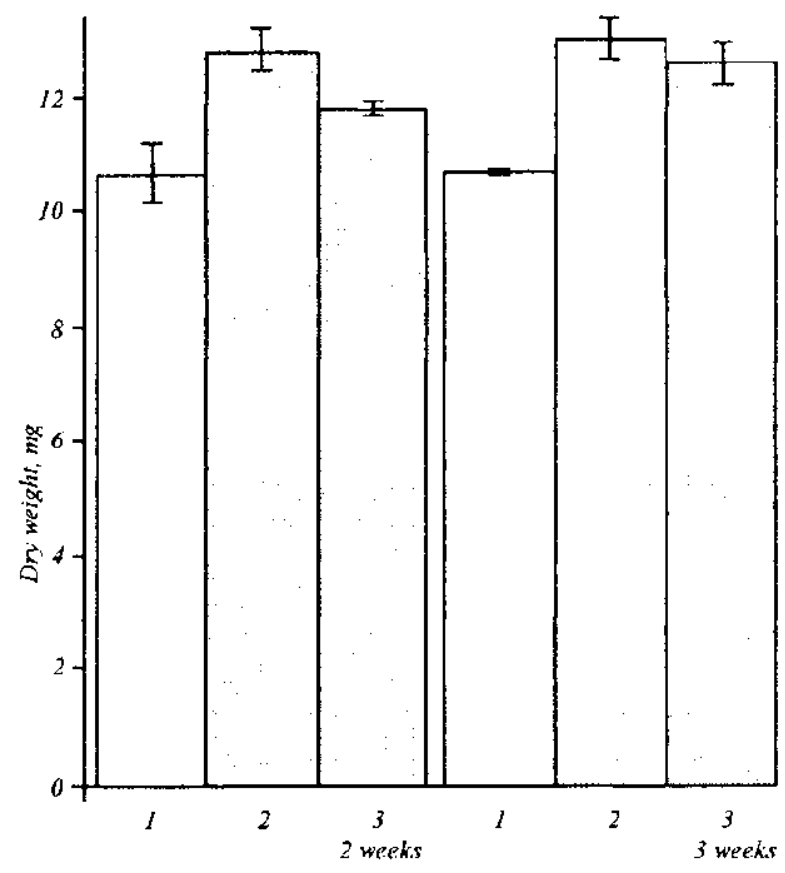

The $K$. oxytoca VN13 influence on biomass of wheat seedlings: I conrol seedlings (without treatment); $2-P e I^{+} ; 3-$ wild type 
plant-hosts from infection by soil pathogenic microorganisms, stimulating the plant immunity. Moreover, endophytes could provide the plant with biologically active substances. Finally, the advantage for endophytes compared to soil bacteria may lay in their capability to preserve a minimal population in the plant tissue, which may serve as a permanent source for external colonization.

It might be postulated that the effect of endophytes on plants depends on the optimai density of internal population. However, nothing is known about possible mechanisms of Klebsiella interaction with the plant which may regulate number of bacteria inside the tissue. Recent years extracellular cell wall degrading enzymes are discussed as elicitors in the infection process of nonpathogenic endophytes $[17-20]$. The pectolytic activity in $K$. oxytoca was documented by von Reisen [8, 9]. Starr et al. [16] confirmed von Reisen's findings and showed that pectolytic Klebsiella possessed pectin lyase and polygalacturonase activities. Chatterjee et al. [21] revealed that $K$. oxytoca excreted only a very small proportion of these enzymes into the growth medium. According to the cell wall degradation in sites, harboring $K$. oxytoca VN13 and $K$. terrigena $80-07$ in rice [2] and wheat \{22\}, we observed and expected pectinases and cellulasaes to take part in entering the plant tissue.

Screening different bacteria of Klebsiella genus for pectinase and cellulase activity revealed the heterogeneity of species with respect to these characters. $K$. oxytoca, $K$. terrigena and $K$. pneumoniae revealed the capability to utilize $P G$ and the only carbon source, in contrast with $K$. planticola.

In our experiments pectate lyase activity of $K$. oxytoca strains was wcak as expected from previous findings of Starr et al. [16] and Chatterjee et al. [21], and it was located mainly inside the cells of bacteria. The low Pel activity may be explained by low numbers of Pel-expressing cells in population $\left(10^{-6}\right.$ to $\left.10^{-5}\right)$. After a passage in selective medium, containing PG, all cells turn out to be $\mathrm{Pel}^{+}$, and the total Pel activity in the $K$. oxytoca population increased.

The increased level of Pel-activity of $K$. oxytoca VN13 correlated with a higher rate of internal colonization of wheat roots. The higher number of cells inside the wheat root interior $\left(10^{4} \mathrm{cfu} / \mathrm{fw} \mathrm{g}\right)$ did not cause pathological changes in th tissue and the Pelstrains did not macerate potato tubers. Cells recovered from the plant roots were $\mathrm{Pet}$, even if seeds were infected by wild type of bacterium. This means that either only cells, recognising and depolymerising pectin, penetrated and spread in the plant tissue, or they became «PG-competent» in the plant interior.
The increased level of $P e l$ activity of $K$. oxytoca VN13 correlated also with better effect on the wheat growth. Seedlings inoculated with $P e t^{t}$-culture exhibited better development, at least during 2 week period of growth.

Acknowledgements. We are grateful for exellent technical assistance to Tamara Voznyuk and Valentine Laschynski. This work was partially funded by Ministry of Science and Technologies of Ukraine (5.4/141) and INTAS UKR-038-96.

\section{Г. Ковтунович, О. Лар, В. Кордюм, Д. Клейнер, H. Козировська}

Посилення внутрішньої колонізації рослин азотфіксуючими бактеріями

Резюме

Декілька итамів Klebsiella oxytoca ma $K$. terrigena, зdamних колонізувати рослини зсередини, виділяли пектат ліазу (ПЛ) - фермент, який деполімеризус клітинну стінку. Активність ПЛ була нижчою, ніж у фітопапогенних бактерій, зосереджувалася всередині клітин Невелика кількість клітин популяції $\left(10^{-6}-10^{-5}\right)$ спроможна рости на селектияному середовищі з полісалактуронатом натрію (ПГ), чкий використовували як джерело вуглецю. Після пасажу через селективне середовище всі клітини набували Pel-фенотипу, $i$ загальна ПЛ-активність $K$. охутоса зростала Підвищена ПЛ-активність бактерій $K$. охуtoса та $K$. terrigena корелювала з посиленням у 10 разів внутрішньої колонізації коренів пиениці. Культура бактерій, яка виростала в селективному середовиці 3 ПГ, краце стимулювала розвиток пиениці, що проявлялося у збільиенні ї̈ біомаси, ніж культура, зроцена без селекції.

Г. Ковтунович, Е. Лар, В. Кордюм, Д. Клейнер, H. Козыровская

Усиление внутренней колонизации растений азотфиксирующими бактериями

Резюме

y нескольких изугенных итаммов Klebsiella охуtоса $и$ K terrigena, cпособных колонизировать растения изнутри, обна ружена активность пектат лиазы (IIJ) - фермента, который деполимеризует клетоиную стенку. Активность ПЛЛ была ниже, чем у фитопатогенньх бактерий, и сосредоточена внутри клетки. Только небольиая часть популяции клеток $\left(10^{-6}-10^{-5}\right)$ способна расти на селективной среде с полисалактуронатом, который использовали в качестве источника услерода. После пассажа через селективиую среду все клетки приобретают Pel-фенотип, и при этом общая ПЛ-активность $K$. oxytoca $и K$. terrigena возрасmает. Повыненная ПЛ-активность бактерий коррелировала с уусилением в 10 раз внутренней колонизации корней пиениць. Культура бактерий K. oxytoca VN13, выросшая в селективных условиях, лучие стимулировала развитие пиениць, что проявлялось в увеличении ее биомассы

\section{REFERENCES}

1. Kordyum V., Kozyrovska N., Gun'kovska N. The theoretical basis and experimental construction of new-type nitrogen fixers able to grow and fix the atmospheric nitrogen in non-legumes // Biopolymery i kletka.-1986.-2.-P. 227-239.

2. Nguyen T., Ton $T$., Tarasenko V., Kozyrovska N. Nitrogen- 
fixing bacteria colonize the rice root xylem // Biopolymery $i$ kletka.-1989.-5.-P. 97-99.

3. Belyavska N. A., Kozyrovska N. O., Kucherenko L. A., Kordyum E. L. Kordyum V. A. Interrelations of Klebsiella with the plant. 1. Electron-microscopy analysis of interaction of the endophytic microorganisms with rice seedling roots // Biopolymery i kletka.-1995.-11.-P. 55-61.

4. Kozyrovska N., Makitruk V., Ruckdashell E. Nitrogen-fixing Klebsiella species produce indole-3-acetic acid // Biopolymery i kletka.-1990,-6.-P. 93-96.

5. Kozyrovska N., Alexeyev M., Kovtunovych G., Gun'kovska N., Kordyum V. Survival of Klebsiella oxytoca VN13 engineered to bioluminescence on barley roots during plant vegetation // Microb. Releases. -1994.-2.-p. 261-265.

6. Huang $J$. Ultrastructure of bacterial penetration in plants // Annu. Rev. Phytopathol. $-1986 .-24 .-$ P. $141-157$.

7. Starr $M . P$. . Chatterjee $A . K$. The genus Erwinia: enterobacteria pathogenic for plants and animals // Annu. Rev. Microbiol.-1972.-26. -P. 389-426.

8. Von Reisen V. L. Polypectate digestion by Yersinia // J. Clin. Microbiol. - 1975.-2.-P. 552-553.

9. Von Reisen V. L. Pectinolytic, indole-positive strains of Klebsiella pneumoniae // Int. J. Syst. Bacteriol.-1976.-26.P. 1 43-145.

10. Kuczius $T$., Kleiner D. Ammonia-excreting mutants of Klebsiella pneumoniae with a pleiotropic defect in nitrogen metabolism // Arch. Microbiol.-1997.-166.-P. 388-393.

11. Miller J. H. Experiments in molecular genetics. - New York: Cold Spring Harbor Lab. publ., 1972.-P. 431

12. Neuer $G$., Kronemberg $A$., Bothe $H$. Denitrification and nitrogen fixation by Azospirillum. III. Properties of a wheatAzospirillum association // Arch. Microbiol.-1985.-141.P. $354-370$.

13. Wood $P$. J. The use of dye-polysaccharide interactions in $\beta$-D-glucanase assay // Carbohydr. Res.-1981.-94.P. 19-23.

14. Ghose T., Montenecourt B. S., Eveleigh D. E. Measure of cellulase activity (substrates, activities and recommendations) // Preprint of JUP AC Commission on Biotechnology, 1981.

15. Cuppels D., Kelman A. Evaluation of selective media for isolation of soft-rot bacteria from soil and plant tissue // Phytopathology. $-1973 .-64 .-P .468-475$.

16. Starr M. P., Chatterjee A. K., Starr P. B., Buhanan G. E. Enzymatic degradation of polygalacturonic acid by Yersinia and Klebsiella species in relation to clinical laboratory procedures // J. Clin. Microbiol.-1977.-6.-P. 379-386.

17. Reinhold-Hurek B., Hurek $T$. Capacity of Azoarcus // New horizons in nitrogen fixation: Proc. 9th Int. Congr. Nitrogen Fixation (6-12 December 1992, Cancun) / Eds R. Palasios, J. Mora and W. E. Newton.-Mexico; Kluwer; Dordrecht, 1992.-P. 671-675.

18. Reinhold-Hurek B., Hurek T., Claeyssens M., van Montagu $M$. Cloning, expression in Escherichia coli, and characterization of cellulolytic enzymes of Azoarcus sp., a root-invading diazotroph // J. Bacteriol. - 1993.-175.-P. 7056-7065.

19. Shishido $M$., Loeb B. M., Chanway C. P. External and interna root colonization of logepole pine seedlings by two growthpromoting Bacillus strains originated from different root microsites // Can. J. Microbiol. -41.-1995.-P. 709-713.

20. Quadt-Hallmann A., Benhamou N., Kloepper J. W. Bacterial endophytes in cotton: mechanisms of entering the plant // Can. J. Microbiol.-1997.-43.-P. 577-582.

21. Chatterjee A. K., Buchanan G. E., Behrens M. K., Starr $M$ $P$. Synthesis and excretion of polygalacturonic acid transeliminase in Erwinia, Yersinia, and Klebsiella species // Can. J. Microbiol.-1979.-25.-P. 94-102.

22. Petak H., Kovtunovych G., Turyanitsa A., Kozyrovska N., Kordyum $\boldsymbol{V}$. Interrelations of bacteria of Klebsiella genus with the plant. 2. Location of Klebsiella oxytoca and $K$. terrigena in tabacco and wheat // Biopolymery i kletka.-1995.-II N 6. - P. 75-80.

УДК 576.851 .155 Received 02.05 .98 